\title{
Who's Afraid of a True European Judicial Culture?
}

\author{
On Judicial Training, Pluralism and National Autonomy \\ Herman van Harten* \\ Assistant Professor, Europa Institute, Utrecht University
}

\begin{abstract}
Judicial training is one of the instruments for the establishment of the area of freedom, security and justice. The Treaty of Lisbon has given the European Union competence in the field of judicial training, particularly in the context ofjudicial cooperation in civil and criminal matters. In September 2011, the European Commission published an ambitious plan for judicial training in the European Union, Building trust in EU-wide justice: A new dimension to European Judicial Training (COM(2011) 551 final). It provides the first concrete goals and objectives within the framework of its 'newly' gained competence in this field. For the purpose of creating a 'true European judicial culture', the European Commission intends to enable approximately 700000 (!) legal practitioners in the European Union to participate in European Judicial Training by 2020 'through the use of all available resources at local, national and European level, in line with the objectives of the Stockholm Programme'.

A major part of the envisaged European judicial training will concern training national judges in EU law. As a result, the plans touch upon several fundamental questions, of which the bottom line is: how does the judge learn EU law? This contribution elaborates on the ambitious Commission's plans and identifies some tentative tensions between the somewhat policy-orientated approach of the Commission by forcing the establishment of a 'true European judicial culture' and national procedural, institutional and judicial autonomy.
\end{abstract}

\section{Introduction}

Speaking of development of law in a pluralistic context, judicial training in the European Union (EU) is an example par excellence. Pluralism in (European) judicial training is undoubtedly present in the EU, especially if one looks at the recently published major survey Judicial Training in the European Union Member States, commissioned for the European Parliament by ERA -

* Contact: h.j.vanharten@uu.nl. 
Academy of European Law. ${ }^{1}$ Differences between national legal systems are reflected in national training structures and national judicial training.

Until recently, the involvement of the EU in this field was quite restrained or, rather, absent. As an example, the research report 'Europeanisation' of the law. Consequences for the Dutch judiciary published in 2005 can be mentioned. This report focuses on the consequences of the 'Europeanisation' process of, in particular, Dutch law for the organization of the Dutch judiciary. The authors note that 'to a large extent the judicial architecture is still left to the discretion of the Member States.' ${ }^{2}$ The authors stress the importance of judicial training and permanent education in the field of European law as a way to cope with major European developments, but it is for the Dutch Council of the Judiciary, which is responsible for financing the training courses in the Netherlands, to decide where financial priorities must lie. ${ }^{3}$

In recent years, the approach and influence of the EU seems to have changed. Partly, because of the changes brought on by the Treaty of Lisbon. September 2011, the Commission published an ambitious plan in the field of European judicial training to train 700 o०o legal professionals in EU law by 2020 . European judicial training is seen as a cornerstone for the development of a 'European judicial culture', or, in the words of the Commission, a 'true European judicial culture'. This plan forms an important part of the implementation of the Stockholm Programme on the development of a European area of freedom, security and justice.

Article 67 of the Treaty on the Functioning of the European Union (TFEU) is the founding provision for the establishment of the area of freedom, security and justice. It stipulates in paragraph 1 that 'the Union shall constitute an area of freedom, security and justice with respect for fundamental rights and the different legal systems and traditions of the Member States.' For the purpose of the development of the area of freedom, security and justice, the EU has gained specific competence in Articles 81 (2)(h) and 82 (1)(c) TFEU for support of training of the judiciary and judicial staff in civil and criminal matters. The Commission's Communication of 13 September 2011 provides concrete goals and objectives within the framework of its 'newly' gained competence in this field.

As a consequence, the EU impact, more specificly the Commission's impact, on European judicial training and judicial training in the Member States will

1 John Coughlan, Jaroslav Opravil, Wolfgang Heusel, ERA - Academy of European Law, Judicial training in the European Union Member States (Brussels: European Parliament 2011) requested by the European Parliament's Committee on Legal Affairs. Available at: www.europarl. europa.eu/delegations/en/studiesdownload.html?languageDocument=EN\&file=6oo91. See, earlier, e.g. also: $\operatorname{COM}(2006) 356$ final, p. 3-4.

2 S. Prechal, R.H. van Ooik, K.J.M. Mortelmans \& J.H. Jans, 'Europeanisation' of the law. Consequences for the Dutch judiciary (The Hague: Council for the judiciary 2005), p. 51.

$3 \quad$ Ibid., p. 48. 
grow evidently in the years to come and will definitely impact the current pluralism in European judicial training in the EU. European judicial training will be used as an instrument to build 'European judicial culture., to establish the European area of justice.

The purpose of this paper is to elaborate on these developments, by focusing on the new dimension to European judicial training, and place them in the broader context of pluralism in European (administrative) law. The current developments touch upon several fundamental questions: how does a judge learn EU law? What is a 'European judicial culture' actually? Is it possible to force the establishment of such a culture through a somewhat policy-orientated approach towards judicial training? Will the new dimension to European judicial training only encompass judicial cooperation in civil and criminal matters?

How do these developments relate to notions of national procedural, institutional and judicial autonomy? How about the judicial independence of national judiciaries and their respective European network structures? What will the influence of the Commission be on the substance of European judicial training? Is this the start of a process of gradually harmonizing judicial training in the EU? And, finally, who will take care of all that European judicial training?

This paper provides some background and an overview of the developments in the field of European judicial training at the level of the EU institutions in the past years $(\mathbb{2} 2)$, followed by a short analysis of the recent Commission Communication ( $\left.\mathbb{\int} 3\right)$. Building trust in EU-wide justice: a new dimension to European judicial training will be placed in a broader context and some tentative tensions will be identified $\left(\mathbb{\int} 4\right)$. Finally, some provisional concluding remarks and elements for discussion will be presented $\left(\mathbb{\int} 5\right)$.

\section{Some Background: the Birth of European Judicial Training}

Until recently, judicial training of the judiciary and judicial staff was solely a competence of EU Member States. However, in the first policy documents on the EU's objective to develop an area of freedom, security and justice, which was introduced in the Treaty of Amsterdam, judicial training was already seen as one of the ways to establish a 'European legal culture', a 'European judicial culture'. For instance, in the Hague Programme, one may read:

'The European Council underlines the need further to enhance work on the creation of a Europe for citizens and the essential role that the setting up of $a$ European Area for Justice will play in this respect. A number of measures have already been carried out. Further efforts should be made to facilitate access to justice and judicial cooperation as well as the full employment of mutual recognition. [...] 
Judicial cooperation both in criminal and civil matters could be further enhanced by strengthening mutual trust and by progressive development of a European judicial culture based on diversity of the legal systems of the Member States and unity through European law. In an enlarged European Union, mutual confidence shall be based on the certainty that all European citizens have access to a judicial system meeting high standards of quality. In order to facilitate full implementation of the principle of mutual recognition, a system providing for objective and impartial evaluation of the implementation of EU policies in the field of justice, while fully respecting the independence of the judiciary and consistent with all the existing European mechanisms, must be established.

Strengthening mutual confidence requires an explicit effort to improve mutual understanding among judicial authorities and different legal systems. In this regard, networks of judicial organizations and institutions, such as the network of the Councils for the Judiciary, the European Network of Supreme Courts and the European Judicial Training Network, should be supported by the Union.

Exchange programmes for judicial authorities will facilitate cooperation and help develop mutual trust. An EU component should be systematically included in the training of judicial authorities. The Commission is invited to prepare as soon as possible a proposal aimed at creating, from the existing structures, an effective European training network for judicial authorities for both civil and criminal matters, as envisaged by Articles III-269 and III-270 of the Constitutional Treaty.' (emp. added $)^{4}$

In response to the request of the European Council mentioned in the last cited paragraph of the Hague programme, ${ }^{5}$ the Commission published a first Communication on judicial training in the European Union on 29 June $2006 .^{6}$ In this Communication the Commission summarizes the evolution of judicial training as an 'essential' instrument for developing the area of justice:

'But justice, which was hitherto only a means of enforcing Community law in the Community, became an objective in its own right under the Amsterdam Treaty. Improvement of judicial cooperation is now an objective to be met. Judicial training is an essential instrument to this end. ${ }^{7}$

4 European Council, 'The Hague Programme: Strenthening Freedom, Security and Justice in the European Union', OJ C 53, 3.3.2005, p. 11-12.

5 This request was repeated in the 'Action Plan to implement the Hague programme', OJ C 198, 12.8.2005, p. 1

6 Communication from the Commission to the European Parliament and the Council on judicial training in the European Union, $\operatorname{COM}(2006) 356$ final.

$7 \operatorname{COM}(2006) 356$ final, p. 2. 
In the opinion of the Commission, and rightly so, this judicial training should concern judicial cooperation in not only civil and criminal matters, because the practices of national administrative law judges may be influenced by European law too:

'[...] judges in the administrative courts, whether or not they belong to the same professional category as the judges in the ordinary courts, must be brought within European debate on training, especially in view of their essential role in matters such as asylum and immigration. Generally, all the judges, including the specialised courts (military judges, neighbourhood judges, justices of the peace, judges in commercial courts, etc.), who may have to apply European law are involved. 8

In the Communication of 2006 , without the Constitutional Treaty being enacted after the French and Dutch 'No' votes, the approach of the Commission is still quite restrained. It realizes that:

'The European Union has no grounds for interfering in the organisation of national training systems, which reflect the Member States' legal and judicial traditions. But strengthening mutual confidence entails developing training sufficiently and devoting sufficient resources to it. [...] European financing can be used only by way of addition to national financing and cannot be used to release the Member States from their responsibility for ensuring an appropriate level of training of the judicial professions.' (emp. added.) ${ }^{9}$

\section{Although:}

'The wish to strengthen judicial training has been clearly affirmed politically on several occasions, and financial support has been forthcoming. [... $]^{10}$

The Commission specifically refers to the European Parliament, which has stressed the importance and 'key role played by training in developing a common legal culture and a culture of fundamental rights within the Union'." The Commission mentions the European Judicial Training Network (EJTN) as one of the organizations with a European dimension involved in judicial training. This association was set up by the national institutions responsible for judicial training in the Member States in 2000. In 2006, the Commission stated:

'The EJTN is a valuable tool for developing judicial training and coordinating the activities of the various national structures in the field of Union law. ${ }^{12}$

$8 \operatorname{COM}(2006) 356$ final, p. 4.

$9 \operatorname{COM}(2006) 356$ final, p. 4.

$10 \operatorname{COM}(2006) 356$ final, p. 4.

$11 \operatorname{COM}(2006) 356$ final, p. 5, with reference to OJ C 304E, 1.12.2005, p. 109.

$12 \operatorname{COM}(2006) 356$ final, p. 6. 
This association received operating grants from the Union budget. In its 2006 Communication, the Commission intended to work out a European Strategy on European judicial training:

'Strengthening legal training involves developing closer relations between national institutions, organisations operating at European level and the Union institutions, particularly the Commission. ${ }^{13}$

Although the approach of the Commission is restrained, in the 2006 Communication the Commission concluded that it may be necessary to opt for a European agency structure in the field of European judicial training at some point in the future:

'Judicial training is a vital issue for the establishment of the European judicial area in the years to come, as the Hague programme stated. Numerous actors will have to be mobilised to play a role here, with a star role for the framework programme on fundamental rights and justice. Concerning the strengthening of the European Judicial Training Network referred to expressly in the Hague programme, financial support appears the most appropriate solution in the current situation. A different option was taken in police matters, where the Union chose a European agency structure when setting up CEPOL. Although a similar solution does not currently seem necessary in judicial matters. The question of developing European judicial training structures towards other forms could be raised again when the framework programme on fundamental rights and justice comes to an end.' (emp. added. $)^{14}$

It is truly interesting to note that the Commission mentions the option of setting up a European agency structure in judicial training matters which 'could be raised again when the framework programme on fundamental rights and justice comes to an end.'

A year later in its Communication A Europe of Results - Applying Community Law published on 5 September 2007, the Commission also mentions the importance of training in European law, it "will ask Member States to confirm the availability of initial and life-long training in Community law for civil servants and judges, with a view to identifying supplementary training that the EU could support. ${ }^{, 15}$

\footnotetext{
$\operatorname{COM}(2006) 356$ final, p. 8.

$\operatorname{COM}(2006) 356$ final, p. 9 .

$\mathrm{COM}(2007) 502$ final, p. 5 .
} 
On 9 July 2008, the European Parliament adopted a resolution on the role of the national judge in the European Union judicial system, ${ }^{16}$ a substantial part of which aims at enhancing judicial training. A survey for the purpose of this resolution highlighted, among other findings, 'the need to improve and intensify the initial and life-long training of national judges in Community.' The European Parliament underlines:

'B. whereas the primary responsibility for judicial training, including its European dimension, rests with the Member States; [...], and whereas the training of the judiciary in each Member State is nevertheless a matter of common concern for the EU institutions and every Member State'

Therefore, the European Parliament calls for a more structured framework for judicial training in the EU:

'15. Calls for the EU component in the training at national level of all members of the judiciary:

- to be systematically incorporated into training for, and examinations to enter, the judicial professions,

- $\quad$ to be further strengthened from the earliest possible stage onwards, with an increased focus on practical aspects,

- $\quad$ to cover methods of interpretation and legal principles which may be unknown to the domestic legal order, but which play an important role in Community law; [...]

19. Takes note of the Commission's assessment that the most appropriate option for promoting training in the European judicial area is currently financial support to various bodies through the Fundamental Rights and Justice Framework Programme for 2007-2013, and that the question of developing European judicial training structures towards other forms could be raised again when that programme comes to an end;

20. Calls on the Commission to evaluate rigorously the results of this framework programme, in the light of this resolution, and to formulate new proposals for the development and diversification of measures to promote professional training for judges;'

The European Parliament even advocates the establishment of a European judicial academy:

'21. Considers, however, that the time is ripe for a pragmatic institutional solution to the question of judicial training at EU level which makes full use of existing structures whilst avoiding unnecessary duplication of programmes and structures; calls, therefore, for the creation of a European Judicial Academy composed of the EJTN and the Academy of European Law; calls for this institutional solution to

$16 \quad(2009 / \mathrm{C} 294 \mathrm{E} / 06)$. 
take account of relevant experience gained in running the European Police College;' (emp. added.)

One of the five focal points of the Stockholm programme, adopted by the European Council on 10/11 December 2009, concerns A Europe oflaw and justice. In this respect, the Council concludes:

'The achievement of a European area of justice must be consolidated so as to move beyond the current fragmentation. Priority should be given to mechanisms that facilitate access to justice, so that people can enforce their rights throughout the Union. Cooperation between public professionals and their training should also be improved, and resources should be mobilised to eliminate barriers to the recognition of legal decisions in other Member States.' (emp. added.) ${ }^{17}$

The Monti report, A new strategy for the single market, identifies the private enforcement of internal market law as a key tool for reduction of the 'compliance deficit' with European law by Member States and an instrument to ensure the effectiveness of the Single Market. ${ }^{18}$ Due to the functioning of EU's judicial system, citizens and businesses are empowered to stand up for their rights before national courts. In the opinion of Monti, private enforcement should be strengthened. The report advocates, as a key recommendation, that 'the Commission, in partnership with Member States, should step up its support for training programmes and structures to ensure that national judges and legal professionals have a solid knowledge of the Single Market rules they are most often required to apply. ${ }^{19}$

In the Action Plan Implementing the Stockholm Programme, under the promising headline 'From political priorities to actions and results', the Commission states: ${ }^{20}$

'Progress in the area of freedom, security and justice requires successful implementation of these political priorities. [...] Our compass will be the Charter of Fundamental Rights and our methodology will be fivefold: better integration with the other policies of the Union; improving the quality of European legislation; better implementation at national level; improving the use made of evalu-

17 Council document 17024/09, adopted by the European Council on 10/11 December 2009, p. 10.

18 M. Monti, A new strategy for the Single Market -At the service of Europe's economy and society, Report to the President of the European Commission José Manuel Barroso, 9 May 2010. Available at: http://ec.europa.eu/bepa/pdf/monti_report_final_10_05_2010_en.pdf.

19 Monti report, p. 102.

20 Communication from the Commission to the European Parliament, the Council, the European Economic and Social Committee and the Committee of the Regions, Delivering an area of freedom, security and justice for Europe's citizens - Action Plan Implementing the Stockholm Programme $\operatorname{COM}(2010) 171$ final. 
ation tools; and matching our political priorities with adequate financial resources, within the multiannual financial framework.

Essential to making real progress will be mutual trust. This requires the establishment of minimum standards (e.g. on procedural rights) as well as understanding of the different legal traditions and methods. A common European culture in this field, through training and Erasmus-style exchange programmes, as well as an European Law Institute, building upon existing structures and networks, can make a valuable contribution and will be actively encouraged. ${ }^{21}$

In the Annex of the Action Plan Implementing the Stockholm Programme,a Communication on an Action Plan on European training for all legal professions is mentioned as a concrete action of the European Commission in 2011. As a response, the European Parliament adopted a resolution on judicial training on 17 June $2010 .^{22}$ In this resolution the European Parliament seems to demonstrate a slightly more nuanced approach towards the supporting role of the EU in the field of judicial training and stresses the sensitivity of the education of judges:

'C. whereas regard must be had to the particular needs of the judiciary in respect of training in the form of familiarisation courses in national, comparative and European law and the sensitivity which needs to be shown in organising such courses,

F. whereas, in spite of the pressure on national budgets, Member States still have the primary responsibility for judicial training and must accept ownership of it,

G. whereas it is nevertheless essential to have EU funding for such judicial training courses designed to foster a European judicial culture,

$\mathrm{H}$. whereas appropriate judicial training and the creation of a European judicial culture can expedite legal proceedings in cross-border cases and hence make a significant contribution towards improving the operation of the internal market for both businesses and citizens and making it easier for citizens who have exercised the right of free movement to obtain access to justice,

I. whereas the Commission should conduct a stock-take of national training programmes and schools for the judiciary with a view also to identifying best practices in this sector,

J. whereas it is necessary to build upon existing structures and networks, in particular the European Judicial Training Network and the Academy of European Law, and involve the Network of the Presidents of the Supreme Judicial Courts, the European Network of Councils for the Judiciary, the Association of the Councils of

21 Communication from the Commission to the European Parliament, the Council, the European Economic and Social Committee and the Committee of the Regions, Delivering an area of freedom, security and justice for Europe's citizens - Action Plan Implementing the Stockholm Programme COM(2010) 171 final, p. 8.

22 European Parliament resolution of 17 June 2010 on Judicial training - Stockholm Programme (P7_TA(2010)0242). 
State and Supreme Administrative Jurisdictions and the Eurojustice network of European Prosecutors-General in the setting up of the pilot projects for judicial training, [...]

2. Calls on the Commission and the Council to ensure that Parliament is fully involved in the conception and approval of arrangements for judicial training, in particular the pilot projects envisaged in the Commission's action plan pursuant to Articles 81 and 82 of the Treaty on the Functioning of the European Union; [...]

4. Calls on the Commission to commence its consultations, in particular of Parliament, with a view to the design and preparation of the future pilot projects as soon as possible;

5. Urges the Commission, with the cooperation of the Member States in the Council, to produce proposals as soon as possible for the creation of a network of legal training bodies across the Union accredited to provide familiarisation courses in national, comparative and European law for members of the judiciary on a stable, ongoing basis;

6. Calls on the Commission to consult Parliament on separate plans for the creation of an institution building upon existing structures and networks, in particular the European Judicial Training Network and the Academy of European Law;

7. Presses the Commission to come forward with concrete proposals for the funding of the future Action Plan for judicial training;' (emp. added.)

\section{The Commission Communication}

The Commission kept its promise by publishing the Communication Building trust in EU-wide justice: A new dimension to European Judicial Training on 13 September 2011. This Communication comprises the action plan for European judicial training. The Commission presents a central ambitious objective to 'enable half of the legal practitioners in the European Union to participate in European judicial training activities by 2020 through the use of all available resources at local, national and European level, in line with the objectives of the Stockholm Programme. ${ }^{23}$

The Communication gives insight into the ambitious plans of the Commission. It begins by stating that the European Union was built on the rule of law combining Union law and national legal systems applied by national courts working in different legal systems and traditions. For the development of the area of freedom, security and justice, the development of a European judicial culture seems absolutely necessary according to the Commission:

$23 \operatorname{COM}(2011) 551$ final, p. 2. 
'The creation of a European judicial culture that fully respects subsidiarity and judicial independence is central to the efficient functioning of a European judicial area. Judicial training is a crucial element of this process as it enhances mutual confidence between Member States, practitioners and citizens. ${ }^{24}$

To realize this ambitious objective, the Commission seeks the support of all relevant stakeholders. It requires 'full commitment and full co-operation' of all stakeholders at all levels. In the Commission's view, 'Member States, the judiciary, judicial schools and legal professions [should] boost their judicial training activities', because they are 'best placed' to make sure that Union law is integrated in national training and 'action at European level will complement national activities'.

Why is it necessary to set up this new action plan for European judicial training? The Commission justifies its plan through the simple fact that Union law has a high impact on the daily life of people and businesses in the EU. National courts are the 'front-line judges' of European law. For the establishment of an area of freedom, security and justice, mutual trust and mutual recognition are essential. Therefore, according to the Commission: 'National judges, at all levels of jurisdiction and all locations from Sicily to Lapland should have an adequate level of knowledge of Union law and national judicial systems'. In addition, effective implementation of Union law is necessary for the purpose of 'legal security and uniform interpretation'.

The Commission explains the new competence of the EU enshrined in Article $81(2)(\mathrm{H})$ and $82(1)(\mathrm{C})$ as 'a clear supporting role for the European Union'. It refers to various previous positions of EU institutions and couples the action plan with the priority as set in the Stockholm Programme Action Plan. It is interesting that the Commission links its action plan for judicial training to both the EU citizenship report $2010^{25}$ and the Europe 2020 Strategy. ${ }^{26}$ However, when reading the EU citizenship report 2010 this link is not as evident as the Commission suggests. At least, there is no concrete link to judicial training. The Commission uses a reference to the Europe 2020 Strategy to make clear that this strategy calls for 'efficient investment in training and for a coherent legal context at European level'. Together with the new legal bases, it brings fresh opportunities 'to create a strong and legitimate framework for training on the Union acquis. ${ }^{27}$ But strangely, the Europe 2020 Strategy does not speak of judicial training as such, it only focuses in general terms on 'the overall quality of all levels of education and training in the EU' under the 'Flagship

\footnotetext{
$24 \operatorname{COM}(2011) 551$ final, p. 2.

$25 \operatorname{COM}(2010) 603$ final.

$26 \operatorname{COM}(2010) 2020$ final.

$27 \mathrm{COM}(2011) 551$ final, p. 3.
} 
initiative: Youth on the move'. ${ }^{28}$ And in that particular context, of Youth on the move, the Europe 2020 Strategy calls Member States to ensure efficient investment in education and training systems at all levels. This does not provide a very solid ground for the action plan in judicial training, and even seems a bit misleading.

The Commission also refers to the European Parliament which, according to the Commission, has consistently advocated a genuine European judicial culture for the development of the European judicial area. ${ }^{29}$ This is true; in several resolutions the European Parliament has pointed out the importance of legal education and training 'to nurture a European judicial culture'. Secondly, the Commission refers to the Stockholm Programme as adopted by the European Council. According to the Commission, these developments together 'call for a step change in the way European judicial training is organised in the Union in terms of concept and scale, so that it is systematically accessible for the legal professionals involved in the implementation of the area of Freedom, Security and Justice. ${ }^{30}$

After a broad consultation of all stakeholders in 2010, the Commission defined core activities and priorities for European judicial training. ${ }^{31}$

Although the legal bases only refer to training of the "judiciary and judicial staff', the Commission takes into account the 'spirit and the aims of the Treatys provisions' so, 'according to the Commission, 'it is possible to extend these provisions' to lawyers and notaries because they are 'an integral and necessary part of judicial activity' or 'contribute to the implementation of Union law'. ${ }^{2}$ While there are feasible arguments for this position, the Commission's interpretation boils down to quite a broad interpretation of the new competence under the Treaty of Lisbon in the field of judicial training. Where are the boundaries of this competence? The wording of the provisions in the Treaty seems to be much more limited. If the Commission chooses this broad approach, for the purpose of creating a European judicial culture, why would the training of legal academics, civil servants or company lawyers not be included?

$28 \operatorname{COM}(2010) 2020$ final, p. 13.

29 It refers to a resolution of the European Parliament of 23 November 2010 on civil law, commercial law, family law and private international law aspects of the Action Plan Implementing the Stockholm Programme (2010/2080(INI)).

$30 \operatorname{COM}(2011) 551$ final, p. 3 .

31 Unfortunately, the summary of the findings of the consultation seem to no longer be available on the website to which the Commission Communication refers:

https://e-justice.europa.eu/content_eu_texts_and_documents_on_judicial_training-121-en.do. $\operatorname{COM}(2011) 551$ final, p. 4 . 
The Commission subsequently refers to (what was then) preliminary data of the ERA - Academy of European Law study for the European Parliament Judicial Training in the European Union Member States. In the EU there are approximately 1401296 legal professionals among whom 79100 are professional judges. Furthermore, it is clear that judicial training activities vary greatly in the Member States.

The Commission decides that priority must be given to judges and prosecutors, who are mainly responsible for the enforcement of Union law, but also mentions that judicial training is essential for all legal practitioners. So, the objective is 'to target all legal practioners whether judges, prosecutors, court staff, lawyers or other legal professionals. ${ }^{33}$

The question is, with respect to all the noble efforts of the Commission in this field, if the new specific competence in Articles 81 (2)(h) and 82 (1)(c) TFEU in support of training the judiciary and judicial staff in civil and criminal matters provides a proper legal basis for such an objective. It is at least questionable. It seems a very broad use of the newly gained EU competence.

The Commission works out its objectives in the rest of the Communication. It aims at a practical approach to European judicial training. It should be relevant for everyday work and encompass initial and continuous training, lifelong learning to stay up-to-date. Member States should see this training as an investment in the quality of justice. Furthermore, the Commission defines priority areas in two categories. ${ }^{34}$ First the whole body of Union acquis should be 'at the centre of European judicial training'. Secondly, the Commission asked the relevant stakeholders to identify training needs in different policy areas. They came up with:

'environmental law; civil, contract, family and commercial law, competition law, intellectual property rights; criminal law (in particular the implementation of the European arrest warrant), crime against Union financial interests; fundamental rights and data protection.'

In addition, the option is mentioned that priorities may also be set 'where the EU has identified low compliance with some sectoral legislation or where sectoral legislation is highly complex and technical.' It concludes that the Commission will take these priority areas into consideration when designing its financial programmes for training.

The Commission presents three additional instruments for the improvement of European judicial training for the benefit of a European judicial area. In the first place, the Commission wishes to develop short-term exchanges for newly 
appointed judges and prosecutors through national judicial training institutions which will increase mutual trust and understanding in judicial systems across Europe. In the second place, investment in e-learning is identified by the Commission as a necessary tool to reach more end-users. For this purpose, the European e-Justice portal will be further developed. Finally, the Commission mentions the importance of language skills for judicial cooperation.

How can these ambitious objectives be realized in practice? The Commission approaches the training objective by 2020 as a shared challenge. In light of the respect of judicial independence and self-organisation of legal professionals, the Commission does not consider it appropriate 'to create a monopoly structure at European level'. It is necessary to build

'on the strengths and experience of existing structures, actors and networks whether national or European. [...] The best option is to support the development of European judicial training activities by all stakeholders, while ensuring that its framework meets all actors' needs, promotes synergies and improvement of training results. ${ }^{.35}$

The Commission then elaborates on the existing strengths at the national level and at the European level though it is not completely clear what the Commission regards as strengths at the national level. The Commission only mentions that existing structures at the national, regional and even the local level are crucial to ensure the inclusion of European law in judicial training. The Commission wants to develop the national level. According to the Commission, training on Union law should be systematically integrated into the initial training of legal practitioners. It calls on Member States and legal professionals to ensure that legal practitioners benefit from at least one week's training on the European acquis during their career. The Commission seeks to reinforce cooperation between stakeholders, consortia or regional groups of national judicial schools to develop common training.

At the European level, the existing judicial training providers and European networks of legal practitioners provide, in the words of the Commission, 'a reliable tool to ensure a significant increase of European judicial training', but 'it is still necessary to bridge gaps in training content, frequency of activities and number of participants. ${ }^{36}$ The European associations of legal professions are key partners with an important coordination role. The Commission makes clear that it will work with ERA and other European training bodies taking into account public and private sector contributions. According to the Commission,

$35 \operatorname{COM}(2011) 551$ final, p. 6

$36 \operatorname{COM}(2011) 551$ final, p. 8. 
public-private partnerships can form an answer to the challenges of a fastchanging European judicial area, 'bodies such as ERA could be central in promoting public-private cooperation' ${ }^{37}$ Also the non-profit European Judicial Training Network is mentioned as a partner at European level, the network of national judicial training structures and ERA. However, the EJTN should 'commit to the reinforcement of the sustainability of its structure and develop a strategy to reach greater numbers of legal practitioners from more Member States.' Therefore, the Commission comes to the conclusion that 'All Member States should commit to reinforcing their financial contribution and the participation of their national judicial training structures in the EJTN to ensure that it has the capacity to play an active role.' And: 'Provided that it demonstrates a reinforced capacity to organise and coordinate judicial training activities, the European Commission will consider even further support. ${ }^{38}$

Given the size of the target audience, the Commission will have to increase its financial support in this field. Therefore, it will boost European judicial training by reinforcing it as a priority in its existing work programmes, and under the new multiannual financial framework, the Commission will consider European judicial training as a major priority to support training of more than 20000 legal practitioners per year by 2020 .

The conclusion of the Communication is that the improvement of judicial training is essential to build a European judicial area to the benefit of people and businesses. A new dimension to European judicial training based on the existing strengths, proven activities and the possibilities of the Treaty of Lisbon is consequently necessary in view of the Commission. This 'new dimension' can be summarized as follows:

'The future European training scheme will be based on actions of:

1. the Member States: building on existing strengths to boost training activities developed by judicial schools or legal professions on the Union acquis;

2. the European-level partners: enhancing their cooperation, increasing the number of activities and exchanges, whether through European-level professional organisations, training providers or the EJTN;

3. the European Commission: increasing its financial support to quality training projects, promoting consortia of judicial schools, aiming at reaching 20 o०o legal practitioners trained at European level per year by 2020 , boosting the use of modern technologies and in particular the European e-Justice Portal. ${ }^{39}$

\footnotetext{
$37 \operatorname{COM}(2011) 551$ final, p. 10.

$38 \operatorname{COM}(2011) 551$ final, p. 9.

$39 \operatorname{COM}(2011) 551$ final, p. 11.
} 
The Commission reaffirms the need for strong commitment of all actors in various forms (budget, time, incentives and clear commitment) 'to ensure that judicial training reaches the level of excellence for a true European judicial culture.'

These combined actions will result in over 700 000 legal practitioners having taken part in a European judicial training session or exchange by 2020 .

On 27/28 October 2011, the 3121st Council meeting on Justice and Home Affairs adopted conclusions on European judicial training on the basis of the Commission Communication. ${ }^{40}$ The Council underlines that judicial training is crucial, and enhances mutual confidence between Member States, practitioners and citizens. The conclusions underline that European judicial training should not jeopardize the independence of the legal and judicial professions. It welcomes the recognition of the 'key role played by training structures at national level'. The Commission's goal to enable half the legal practitioners in the EU to participate in European judicial training activities by 2020 has now become a genuine EU goal.

In a resolution on judicial training, adopted on 14 March 2012, the European Parliament developed its own view on the Commission's notice and gives further impetus for the Commission's 2020 target partly because 'the supply of training is currently far from meeting' that target according to the European Parliament. ${ }^{41}$ The approach of the European Parliament is more orientated from the perspective of the (national) judiciaries and national judicial training schools. Typical is the observation that 'the best people to provide judicial studies are judges themselves', and the resolution stresses the need to take advantage of the existing institutions, particularly national judicial training schools and EU law coordinators within national court structures, such as those that exist in Italy and the Netherlands. Furthermore, the resolution is focused on various possibilities to benefit from modern information and communication technology for the realization of the Commission's objective, and even explicitly considers the creation of applications ('apps') similar to Apple's iTunes for European judicial training.

40 See: www.consilium.europa.eu/ueDocs/cms_Data/docs/pressData/en/jha/125749.pdf.

41 European Parliament resolution of 14 March 2012 on judicial training (2012/2575(RSP)). 


\section{Who's Afraid of a True European Judicial Culture?}

The efforts laid down in the Commission Communication seem very noble, and to be fair, one may question if there is any reason to be critical about it: who is afraid of a true European judicial culture? Is it not a noble goal for an 'ever closer Union'? Besides, everything is still predominantly in the field of policy setting, so why bother as a jurist? Still, between the lines one may get the impression that the approach the Commission takes on this, and, similarly, to some extent, for the European Parliament, is a bit too policyorientated. By developing a strong policy in the field of European judicial training, the EU wants to force the establishment of even a true European judicial culture. In the Commission's view, strong commitment of all actors in various forms (budget, time, incentives and clear commitment) is necessary 'to ensure that judicial training reaches the level of excellence for a true European judicial culture'. But because it all concerns the education of judges in the EU Member States and because of the (potentially) wide impact of this judicial training on the judiciaries in the Member States especially, the idea occurs that Something Big is going on, a development that deserves further attention and reflection.

To be clear, I am not afraid of the big bad wolf, 'Red, Yellow and Blue' or of the development of a European judicial culture - whatever that may be, other than a slogan. It is true in practice a fascinating process is already taking place gradually in judicial cooperation between courts in the Member States..$^{42}$ It is mainly challenging to place some question marks by the way, in the words of the Commission, the creation of a European judicial culture takes place through the published plans. In the introduction of this paper various questions were posed. It was stated that the current developments touch upon several fundamental questions. Let us try to place the action plan of the Commission in a broader context of pluralism in European law and see if some tentative tensions can be identified.

First of all, a disclaimer - at least to some extent. Much depends on the chosen perspective of how we evaluate Building trust in EU-wide justice: A new dimension to European Judicial Training. The author of this paper is educated in a certain

42 During my PhD research on autonomy of national courts in EU law, I came across only a few examples in which Dutch courts refer to cases on EU law from other national courts. For example the Betfair case of the Dutch Council of State can be mentioned here. The Council of States uses the fact that the German Verwaltungsgerichte did refer the gambling case of Markus Stoss to the European Court of Justice for a preliminary ruling as an argument to decide to refer the gambling case of Betfair to the ECJ too. Interesting is the fact that the Dutch Supreme Court used the Betfair judgment as an argument to send a similar case to Luxemburg for a preliminary ruling as well. I think this development in the practice of the courts of Member States is still in its infancy and will develop further in the years to come. 
school of thought, that of a shared legal order in the EU, the school of the authors of Europeanisation of public law. In their conclusion of Europeanisation of Public Law in 2007, Jans et al writes: 'In a shared legal order, Union interference in national law must remain limited to what is essential. ${ }^{43}$ So, pluralism seems to be the rule, harmonization the exception.

Such an approach leads us to some first impressions. Is using the limited legal bases for support of judicial training in judicial cooperation in civil and criminal matters in such a broad and general manner, directed towards all legal practitioners in EU Member States, essential or is it far more than essential? Can the Commission actually use these legal bases for providing European judicial training of administrative law judges in the EU Member States? And is it essential to interfere in the judicial training for lawyers and notaries? The answers seem to be in the negative. There is not much reason to attempt to attain a farreaching uniformity of European judicial training. The role of the EU should be, according to the legal bases in the Treaty, 'supporting'.

And although, in its Communication of September 2011, the Commission stresses that the creation of a European judicial culture should fully respect subsidiarity and judicial independence, ${ }^{44}$ this fully fleshed approach, the new dimension to European judicial training seems to suggest between the lines that the Commission will get a (further) grip on the Europeanisation of national judiciaries and their organization step by step. Is it for the EU, and the Commission in particular, to take over the (European) judicial training? Training of national judges is not just another policy field. National judges are not executive 'parts' of European governance, they do, or at least they should, operate in a far more independent and autonomous way.

Europeanisation of law is certainly not always a one-way direction and is not, and should not be seen as, a process which can be forced by a top-down approach, there is always a bottom-up dimension. ${ }^{45}$ However, throughout the Communication, the approach of the Commission seems written from a far more top-down approach. For instance, what about educating on national European case law? Although the Commission uses the input of stakeholders to identify priority areas for judicial training, it seems as if it is the Commission

43 J.H. Jans, R. de Lange, S. Prechal \& R.J.G.M. Widdershoven, Europeanisation of public law (Groningen: Europa Law Publishing 2007), p. 369.

$44 \operatorname{COM}(2011) 551$ final, p. 2.

45 See the edited volume of the first REALaw Research Forum: K.J. de Graaf, J.H. Jans, A. Prechal \& R.J.G.M. Widdershoven (eds), European Administrative Law; Top Down and Bottom Up (Groningen: Europa Law Publishing 2009). 
or the EU only which decides top-down, where to set the priorities in European judicial training.

The Commission states that it will build on existing structures and European judicial networks. It uses the vehicles of the rather informal networks, in the words of the Commission 'for a step change in the way European judicial training is organized in the Union in terms of concept and scale'. To be fair, the Commission acknowledges the need to ensure the necessary respect of judicial independence and that it would not be appropriate to create a monopoly structure on the EU level for judicial training. According to the Commission, the best option is to support the development of European judicial training activities by all stakeholders, and it intends to use the existing strengths at national, regional and local level. However, the Commission also states: 'existing judicial training providers and European networks of legal practitioners provide a reliable tool to ensure a significant increase of European judicial training' (something which is not mentioned in the paragraph on existing national strengths). So, it seems as if the Commission will use mainly the EU judicial networks as agents for the soft harmonization of judicial training in the EU, because for reaching the ambitious goal the Commission requires 'the commitment and full co-operation of stakeholders at all levels.'

In the mean time, the most prominent European judicial networks have been established by the actors on the national level themselves. Most of them have been set up by national judges in a particular field of law or from a particular branch of courts. ${ }^{46}$ Most of them are still quite informal in character, but some of them do publish various reports on developments in EU law which have a nature of bottom-up advocacy at some points. Other judicial networks have been established within an EU legal framework and these play a specific role in mutual recognition between courts in EU member states. However, it certainly is not always the case that these networks have similar ideas on how the legal evolution of EU law should take place from a purely top-down perspective. For instance: the approach of the 2008 report of the functioning of the preliminary reference procedure by the Association of Councils of State and Supreme Jurisdictions of the European Union may be mentioned as a striking example. ${ }^{47}$

One essential question is: how does the judge learn EU law? In fact this goes for all the 700 ooo legal professionals who will be trained. How will they learn

46 See for a recent overview and analysis: M. Claes \& M. de Visser, 'Are You Networked Yet? On Dialogues in European Judicial Networks', Utrecht Law Review 2012-2, p. 100-114.

47 See for instance the report of the working group on the preliminary ruling procedure of the Association of the Councils of State and Supreme Administrative Jurisdictions of the European Union, published in its Newsletter nr. 20, 2008; available on: www.juradmin.eu. 
European law? Top-down? Bottom-up? Combined? Through the glass of Simmenthal or Rewe $?^{48}$ It is relevant for various fields or elements of EU law. To give two examples: we could think of the how to interpret the 'obligation to refer' for courts of last instance in the preliminary reference procedure: following the wordings and strict lines of the Cilfit case ${ }^{49}$ or with a more common sense approach? The different approach to the objectives of EU competition law between the European Court of Justice and the Commission also provides an example. ${ }^{\circ}$ It all boils down to the question of how much influence the Commission will have on the substance of the judicial training programmes and the establishment of the 'true European judicial culture'. From that point of view, there are some tentative, possible tensions to be distinguished.

First, Article 67 TFEU, the basic provision on the area of freedom, security and justice, explicitly states that, apart from fundamental rights, the different legal systems and traditions of the EU Member States should be respected. The efforts for forcing the establishment of a true European judicial culture may at some point clash with respecting differences and traditions of the legal systems in the EU Member States.

Secondly, all depends on the perspective one has on the autonomy of EU law and the relationship between EU law and national law, the role of national procedural autonomy and the role of national actors for further substantiation of EU law. What is the role of national courts? A pure bouche de la loi or judges with a role of their own in the EU judicial system? Should they always follow an approach similar to that of the Commission, or do they have the freedom to decide otherwise?

Thirdly, as stated above, the way the European Commission will be involved in this field is of vital importance. There may be tension between national institutional autonomy on the one hand, and the goal of the Commission on judicial training on the other. Because of the fact that it concerns, at least for a substantial part, an action plan directed at European judicial training of judges, the role for the Commission must be different compared to, for instance, the role it plays in the European Competition Network and the Networks of Sectoral Su-

48 The reasoning from the CJEU in the Case 106/77 Simmenthal [1978] ECR 629 focuses on the autonomous nature of Union law and that it takes per definition precedence over any conflicting national rule. The reasoning from the CJEU in the Case 33/76 Rewe [1976] ECR 1989 is centered around the principle of procedural autonomy: national procedural rules apply, unless Community law provides otherwise and the requirements of the principle of equivalence and principle of effectiveness are fulfilled.

49 Case 283/81 Cilfit [1982] ECR 3415.

50 See for instance Joined Cases C-501/06P, C-513/06P, C-515/o6P and C-519/06P GlaxoSmithKline Services Unlimited $v$ Commission [2009] ECR I-9291. While the Commission claims consumer welfare as the central goal of competition law, the CJEU highlighted three different objectives of competition law: protection of economic freedom, protection of consumers and their welfare and European market integration. 
pervisors. Furthermore, it may be submitted that there will never be a 'true European judicial culture' if the fact that the judges within the Member States have a specific, autonomous role of national courts in EU law is not properly taken into account..$^{51}$

\section{Concluding Remarks and Elements for Discussion}

The action plan of the Commission in the field of judicial training as published in the Communication Building trust in EU-wide justice: a new dimension to European judicial training has very ambitious objectives. Its approach seems to be much more wide-ranging than just supporting the training of judiciary and judicial staff for the sole purpose of judicial cooperation in civil and criminal matters in the EU. This results in tension between the action plan and the legal bases of the specific and limited EU competence in Articles 81 (2)(h) and 82 (1)(c) TFEU.

The 'step change in the way European judicial training is organized in the Union in terms of concept and scale' will undoubtedly change the impact of the EU on European judicial training. The proposed ambitious reinforcement of judicial training leads us to various fundamental questions on the division of competence between the EU and its Member States in this field and, for instance, the relationship between judicial training, the Commission's influence and autonomy of national courts in EU law. Question is if the end (a true European judicial culture - whatever that may be) justifies the means. At least, our topic evidently provides further food for thought and discussion. On a wide spectrum: Is there actually a problem at all? Or marks the ambitious Commission's initiative essentially the end of pluralism in the field of European judicial training? What is actually a 'true European judicial culture'? How much influence will the Commission have on the substance of the (European) judicial training programmes? Who will be educating whom? What about the institutional balance between autonomy of national courts and the involvement of EU administration? Does developing a 'European judicial culture' by providing a European judicial training policy constitute harmonization through the back door, by getting a further grip on the Europeanisation of national judiciaries and their organization step by step? Should, for instance, the European Judicial Training Network, or the other Member State organised European networks involved in judicial training develop an own perspective on the autonomous role of national courts in EU law? These questions certainly boil down to the

${ }^{51}$ See furthermore Herman van Harten, Autonomie van de nationale rechter in het Europees recht. Een verkenning van de praktijk aan de hand van de Nederlandse Europeesrechtelijke rechtspraak over de vestigingsvrijheid en het vrijedienstenverkeer (Den Haag: Boom Juridische Uitgevers 2011). 
need to further develop ideas on the future role of national courts in the EU's judicial system, the 'true European judicial culture' and EU's area of justice. 